SEAWOMIR DRELICH Instytut Filozofii UMK

\title{
UNIWERSYTECKI ETHOS W DOBIE GLOBALIZACJI I INTERNETU
}

\author{
„Nauczyciel uniwersytecki jest \\ przede wszystkim sługa prawdy obiektywnej, \\ przedstawicielem jej i głosicielem" \\ Kazimierz Twardowski ${ }^{1}$
}

\section{Globalizacja i przemiany przez nią warunkowane}

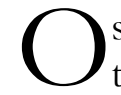
statnie kilkadziesiąt lat (w Polsce - kilkanaście) to czas narastania tzw. procesów globalizacyjnych. W sferze gospodarki procesy te doprowadziły do utworzenia się jednego rynku światowego zdominowanego przez spółki i konsorcja międzynarodowe, opierającego się na swobodnym i niczym niemalże nieskrępowanym przepływie kapitału. Globalizacja w sferze politycznej wiąże się z rosnącym znaczeniem ponadnarodowych organizacji i instytucji, odsuwaniem na tor dalszy interesów państw narodowych, na rzecz pojętych swoiście interesów regionalnych. Aspekt społeczny tychże procesów obrazuje najlepiej metafora „globalnej wioski” - świata zanikających granic, swobodnie podróżujących i przemieszczających się ludzi, posiadających nieograniczony wręcz dostęp do informacji. Te trzy płaszczyzny w sposób konieczny implikować muszą zmiany w sferze kulturalnej. Mieszkaniec owej „globalnej wioski” nolens volens dostosowuje swoje codzienne życie i życiowe cele do szybko zmieniającego się świata, zaś

\footnotetext{
${ }^{1}$ T. Czeżowski, W sprawie deontologii pracownika naukowego, w: Pisma z. etyki i teorii wartości, pod red. Pawła J. Smoczyńskiego, Zakład Narodowy im. Ossolińskich, Wrocław 1989, s. 230.
} 
media masowe podsuwaja mu gotowe rozwiąania i sposoby realizacji tychże celów ${ }^{2}$.

\section{Edukacja w świecie zglobalizowanym}

Przemiany, jakie mają miejsce w ramach wspomnianych powyżej trzech sfer życia (gospodarczej, politycznej i społecznej), dotknąć muszą również sfery kulturalnej, a w szczególności - edukacji. Edukacja bowiem znajduje się pod ciagłym wpływem zarówno ekonomii, jak i polityki, czy społeczeństwa. J. Delors przyjmuje, że edukacja musi się do wszystkich zachodzących we współczesnych społeczeństwach zmian dostosowywać, musi pod katem tych zmian wytyczać sobie nowe cele a także - korzystając ze zdobyczy społeczeństw zglobalizowanych przyjmować nowe metody i techniki tychże celów realizacji. Edukacja rozumiana szeroko jako proces uczenia się ma - według Delorsa - trzy zasadnicze cele: 1) zdobywanie wiedzy, 2) skuteczne działanie oraz 3) harmonijne współżycie z innymi ludźmi - uczymy się, aby wiedzieć, działać i wspólnie żyć3.

Szkoły i uniwersytety, jako instytucje powołane, aby przekazywać młodemu człowiekowi wiedzę, sprostać muszą wyzwaniom, jakie stawia przed nimi współczesny świat opierający się przecież na ciągłym obiegu informacji, dzięki której zakres ludzkiej wiedzy ulega nieustannemu poszerzaniu ${ }^{4}$. Instytucje edukujące człowieka stają się pierwszym filtrem, przez który „przepuszczony” zostaje informacyjny strumień, zewsząd atakujący człowieka współczesnego. Często jest to informacja oderwana od jakiegokolwiek kulturowego kontekstu, pozostająca bez najmniejszego związku z nasza przeszłością, informacja do niczego nam nie przydatna, w najmniejszym stopniu nie pomagająca nam w realizacji naszych celów. Jest ona co najwyżej dowodem i przejawem pokawałkowanego, zatomizowanego świata ${ }^{5}$. Zadaniem szkól i

\footnotetext{
${ }^{2}$ Zob. T. Zasępa, Globalizacja - mass media - Internet, w: Internet $i$ nowe technologie - ku społeczeństwu praysz̨łości, pod red. Tadeusza Zasępy, Radosława Chmury, Edycja Świętego Pawła, Częstochowa 2003, s. 11-15.

${ }^{3}$ A. M. de Tchorzewski, Edukacja wobec problemów transformacji, integracji i globalizacji, w: Etos pedagogów $i$ edukacji wobec problemón globalizacji, pod red. Urszuli Ostrowskiej, Andrzeja M. de Tchorzewski, Akademia Bydgoska im. Kazimierza Wielkiego, Uniwersytet Warmińsko-Mazurski, Bydgoszcz - Olsztyn 2002, s. 25.

${ }^{4}$ M. Lubański, Informacja - system, w: Zagadnienia filozoficzne wspótczesnej nauki. Wstęp do filozofii prayyrody, pod red. Michała Hellera, Mieczysława Lubańskiego, Szczepana Ślagi, Warszawa 1980, s. 103-107.

5 M. Hetmański, Wiedza i informacja w spoteczeństwie obywatelskim, w: Internet $i$ nowe technologie, dz. cyt., s. 47.
} 
uniwersytetów jest przede wszystkim rozpoznanie informacji istotnych i przydatnych, wyrugowanie tego, co jedynie „zaśmieca” i komplikuje, wybranie tego, co z naszego punktu widzenia może wydawać się ważne i przydatne. Taka rola instytucji edukacyjnych - rola swoistego filtra informacyjnego - sprawia, że współczesna szkoła i uniwersytet otrzymuja odpowiedzialne i trudne zadanie. Rugowanie informacji nieprzydatnych i „zaśmiecających” (tzw. „spamu”) nie może stać się cenzura, a przekazywanie wiedzy istotnej i użytecznej - indoktrynacja.

Zdobyta wiedza ma stać się przede wszystkim wiedzą praktyczna, przydatną w działaniu, to działanie uskuteczniającą. W sposób szczególny chodzi tutaj o te działania, które związane są z największymi zagrożeniami i niebezpieczeństwami ogólnoświatowymi: głodem, bieda, ubóstwem, wojnami czy terroryzmem. Edukacja współczesna ma z jednej strony uświadomić człowiekowi istnienie tych niebezpieczeństw, pokazać te największe problemy dzisiejszych czasów, z drugiej zaś strony - wskazać możliwości i sposoby walki z nimi bądź przynajmniej poszukiwać sposobów na ich rozwiązanie ${ }^{6}$. Pewnym ograniczeniem świata zglobalizowanego jest fakt, że w większym stopniu jest on „cyberświatem” czy też „cyberspołeczeństwem”, wobec czego większość działań, o jakich tutaj mowa, odbywa się on line. Rzeczywiste problemy świata realnego nie zawsze jednak moga zostać rozwiązane w świecie wirtualnym ${ }^{7}$. Człowiek współczesny jednakże chciałby działać i realizować możliwie wiele spośród swoich celów nie ruszając się z domu czy wręcz nie odwracając głowy od ekranu komputera. Wzrost aktywności w „cyberświecie” może prowadzić do dezaktywizacji w świecie rzeczywistym.

Podobne następstwa dostrzec można w sferze kontaktów interpersonalnych. Człowiekowi ery informacyjnej łatwiej kontaktować się z innymi ludźmi, poszerzać kragg swoich znajomych i przyjaciół o ludzi mieszkających po drugiej stronie świata, wymieniać się z nimi doświadczeniami. Coraz częściej człowiek ów czuje się przede wszystkim obywatelem świata, co z jednej strony poszerza jego horyzonty, z drugiej zaś - odrywa od świata, w którym się urodził, zaś tożsamość jego czyni tożsamością pograniczna, czerpiąca z różnych tradycji i kulturowych projektów $^{8}$. Już Tadeusz Czeżowski dostrzegal, że „w okresach gwałtowanych przemian społecznych i połączonych $z$ nimi

${ }^{6}$ A. M. de Tchorzewski, dz. cyt., s. 22.

7 A. Lekka-Kowalik, $C_{z y}$ cybernetyka wystarczy cyberspoleczeństwu?, w: Internet $i$ nowe technologie, dz. cyt., s. 18-19.

8 E. Kubiak-Szymborska, Edukacja wobec 'bycia globalizowanym' $i$ zycia we wspótçesnej megalopolis, w: Etos pedagogów i edukacji, dz. cyt., s. 33-34. 
przewartościowań ów utrwalony tradycją system deontologii i należący doń ideał doskonałości zostaje rozbity”. Człowiek ,zatopiony” w sieci, zawieszający swoje istnienie realne i poddający się rzeczywistości wirtualnej inaczej wyobraża sobie współżycie z innymi ludźmi. Telefony komórkowe i Internet sprawiają, że można „być z ludźmi” nie odwracając głowy od monitora komputera. To ,ja” siedzące przed komputerem decyduje, kiedy porozmawia czy „spotka się" z innym „ja” siedzącym przed komputerem. Współczesna edukacja staje więc przed problemem, którym jest niewątpliwie zerwanie dotychczas łączących ludzi więzi społecznych. Szkoła i uniwersytet - wykorzystując najnowsze drogi komunikacji - muszą sprawić, by tożsamość pograniczna nie stała się brakiem tożsamości, a nowe formy „bycia z innymi” nie prowadziły do całkowitego „bycia bez innych”, samotności czy zagubienia.

W obliczu tak wielkich zmian wielu współczesnych filozofów i etyków proponowało zdefiniowanie nowego ethosu, który można by nazwać ethosem globalnym. Ethos ów byłby właśnie rozwiązaniem tychże problemów, stałby się budulcem stosunków między ludźmi, grupami społecznymi, społecznościami oraz państwami. Nie może on jednak być konstruktem całkowicie nowym, opierać się powinien na dotychczasowych tradycjach i filozofiach, aby zachować ciagłość między tym swoistym novum a ethosem dotychczas obowiązującym ${ }^{10}$. Pierwszy pomysł tak rozumianej uniwersalnej etyki globalnej stworzył Hans Küng. Fundamentami takiej etyki powinny być: wyzbycie się agresji i szacunek do życia, solidarność i troska o sprawiedliwy porządek, tolerancja i życie w prawdzie, równouprawnienie i partnerstwo między kobietami a mężczyznami ${ }^{11}$. Kryteria takiej etyki globalnej musiałyby obowiązywać również w sferze edukacyjnej, co więcej: instytucje takie, jak szkoła czy uniwersytet, byłyby zobowiązane do krzewienia i uczenia młodych obywateli świata tejże etyki. W ten sposób owa tożsamość pograniczna zostałaby zastąpiona swoiście rozumianą uniwersalną tożsamościa globalna.

\footnotetext{
9 T. Czeżowski, W sprawie deontologï pracownika naukowego, w: Pisma z. etyki i teorii wartości, dz. cyt., s. 229.

${ }^{10} \mathrm{H}$. Küng, Globalisierung erfordert ein globales Ethos, Collegium Europaenum Jenense, Friedrich-Schiller-Universität, Jena 2000, s. 25.

${ }^{11} \mathrm{D}$. Zając, Uniwersalna etyka zawodowa nauczyciela - jej szanse $i$ dylematy, w: Etos pedagogów $i$ edukacji, dz. cyt., s. 166.
} 


\section{Nowe i stare cele uniwersytetów}

Hans Küng postuluje, aby propagowanie globalnej etyki uniwersalnej stało się nowym celem uniwersytetów. Czy jednak rzeczywiście byłoby to dla uniwersytetów zadanie nowe, co do tego raczej zgodzić się nie można. Od wieków bowiem przyjmowano, że uniwersytet to nie tylko wspólnota przygotowująca do wykonywania określonego zawodu i zaopatrująca w potrzebny zasób wiedzy i umiejętności. Miał on być również wspólnotą przysposabiająca młodego człowieka do funkcjonowania w życiu społecznym, stąd właśnie z konieczności musiał uczyć młodych jakiegoś ethosu. Miała to być swoista „edukacja do życia”. Współcześnie cele uniwersytetów są takie same, przy czym ze względu na szereg zjawisk, jakie w naszej kulturze miały i nadal maja miejsce, pewnej zmianie ulec musiał ów ethos, jaki w ramach uniwersytetu miałby być pielęgnowany. Już Tadeusz Czeżowski pisząc o ideale uniwersytetu zauważył, że środowisko uniwersyteckie nie może pozwolić sobie na skostniałość i anachroniczność, zawsze musi podążać „z duchem czasów”. Za najważniejsze czynniki na ów ethos współcześnie wpływające uznał: umasowienie kultury i zwiększony napływ młodzieży studiującej, rozrost nauki i powstawanie kolejnych dyscyplin naukowych oraz wzrost współuzależnienia nauki i innych dziedzin życia społecznego ${ }^{12}$. Współczesny uniwersytet musi być instytucją otwartą na szerokie rzesze młodych ludzi, ludzi często odmiennych światopoglądów i odwołujących się do różnych tradycji. Musi być instytucją otwartą na przyjmowanie nowych, zmieniających ją, recept i rozwiązań. Musi ponadto być instytucją otwartą na świat, wykorzystującą zdobycze i osiągnięcia innych sfer życia.

Przyglądając się w ten sposób uniwersytetowi współczesnemu konstatujemy, że z instytucji „edukującej do życia” stał się wręcz instytucja „edukującą całożyciowo”. Chodzi tutaj zarówno o notoryczne, systematyczne i nieprzerwane samokształcenie ludzi, którzy w ramach wspólnoty uniwersyteckiej funkcjonuja, ale również o kształcenie ludzi, niezależnie od ich wieku i ich pozycji społecznej. Często wskazuje się, że działanie współczesnego uniwersytetu jest przede wszystkim formowaniem „modelowego człowieka, etosowego humanisty, wymaga (...) edukacji całożyciowej i ustawicznego wspierania tego złożonego procesu przez wszystkie struktury kulturowe, ekonomiczne, polityczne,

12 T. Czeżowski, O ideale uniwersytetu, w: Pisma z etykei i teorii wartości, dz. cyt., s. 238. 
religijne i społeczne” ${ }^{13}$. Zadaniem najważniejszym takiej „edukacji całożyciowej” byłoby podtrzymywanie dialogu między poszczególnymi ludźmi, grupami społecznymi czy kulturami oraz poszerzanie sfery komunikacji i porozumienia. Takie podejście wymuszane jest również przez rzeczywistość współczesnych państw i społeczeństw demokratycznych, funkcjonowanie swoje opierających głównie na takich wartościach, jak wolność sumienia oraz pluralizm szeroko rozumiany. Uniwersytet czasów dzisiejszych powinien uczyć człowieka odpowiedzialności za jego działania, słowa i poglądy a także szacunku dla poglądów innych ludzi, dzięki któremu konflikty i spory natury ideologicznej, światopoglądowej czy politycznej - powszechne przecież w demokracjach - będą konstruktywne ${ }^{14}$ i zawsze przebiegać będą z poszanowaniem wszelkich ogólnie przyjętych zasad dyskutowania ${ }^{15}$.

Współczesny uniwersytet, wspólnota i instytucja dostosowująca się do otaczającego świata i kondycji współczesnego człowieka, musi być otwarty również na stosowanie nowych czy innowacyjnych metod kształcenia studentów oraz docierać musi do młodych ludzi wszelkimi dostępnymi kanałami ${ }^{16}$. Student - czy szerzej: osoba kształcąca się musi mieć możliwość dostosowania oferty edukacyjnej, jaką dysponuje uniwersytet, do własnych indywidualnych zainteresowań. Również zestaw technik kształcenia musi zostać tak urozmaicony, aby „,człowiek zglobalizowany" mógł wybrać tę, która jemu wydaje się najbardziej odpowiednia, zaś jej zastosowanie maksymalizować będzie skuteczność procesu kształcenia. Celem powinno być kształcenie „twórczej indywidualności”, zaś „kształcenie indywidualności jest wszechstronnym rozwijaniem jej możliwości, twórczość osiąga się kształcąc samodzielność myślenia" ${ }^{17}$. Stąd na niektórych kierunkach studiów programy nauczania kształtowane są tak, aby student sam decydował o wyborze zajęć, na które będzie uczęszczał, natomiast przedmioty

\footnotetext{
13 Z. Lomny, Imperatyw etosowej i bumanistycznej stǘby nauki na rzecz bezpiecznej i sprawiedliwej prayszłości swiata, w: Etos edukacji w XXI wieku, pod red. Ireny Wojnar, Komitet Prognoz „Polska 2000 Plus” przy Prezydium PAN, s. 49.

14 W. Sawczuk, Edukacja wobec problemów globalizacji-wymiar aksjologiczny, w: Etos pedagogón i edukacji, dz. cyt., s. 42.

15 Wystarczy wspomnieć wymagania, jakie przed dyskutantami stawiał Tadeusz Czeżowski. Do wymogów naukowych zaliczył: (1) wyraźne postawienie zagadnienia będącego celem dyskusji, (2) posługiwanie się przez wszystkich uczestników tym samym językiem fachowym oraz (3) uzasadnianie twierdzeń w sposób odpowiedni dla nauki, często z wskazaniem przykładu. Zob. T. Czeżowski, O dyskusji i dyskutowaniu, w: Odcryty filozoficzne, Towarzystwo Naukowe w Toruniu, Toruń 1969, s. 192-193.

16 Tenże, O ideale uniwersytetu, w: Pisma z. etyki i teorii wartości, dz. cyt., s. 238-239.

17 Tamże, s. 240.
} 
obligatoryjne są ograniczane do tzw. minimów programowych, zawierających przedmioty ogólnohumanistyczne czy ogólnotechniczne, zapoznające $\mathrm{z}$ podstawami funkcjonowania naszego kręgu cywilizacyjnego oraz te, które dostarczyć mają studentowi konieczny zasób wiedzy związanej z jego kierunkiem studiów. Oczywiście, nie wszystkie jeszcze jednostki uniwersyteckie dostrzegły zalety tego systemu, jednak wydaje się, iż ku temu ideałowi większość z nich podąża ${ }^{18}$.

\section{Meandry edukacji wirtualnej}

Szczególne znaczenie dla procesu edukacji w czasach współczesnych ma Internet czy też nowe media. Internet wydaje się być niezwykle istotnym narzędziem realizacji owych - na nowo zdefiniowanych - celów uniwersytetu. Hans Küng pragnął, aby zaproponowana przez niego etyka globalna stała się systemem zasad uniwersalnym i powszechnym, tak szerokie rozpowszechnienie takiej etyki mogłoby być możliwe poprzez Internet właśnie. Internet mógłby również realizować zadanie kształcenia ustawicznego z zastosowaniem innowacyjnych metod i technik. Nie można również zapomnieć, że jest to nieskrępowane medium pozwalające na swobodną wymianę informacji - to zaś dla uniwersytetów, jako jednostek „rozpowszechniających wiedzę”, powinno być niezwykle istotne. Podobnie zresztą wykorzystują Internet kościoły i związki wyznaniowe, których celem jest, by ich nauka „promieniowała we wszystkich społecznościach ludzkich"19. Arcybiskup katolicki John Foley przekonywał, że „Internet oferuje Kościołowi możliwość, by zachowane przesłanie Jezusa Chrystusa uczynić dostępnym dla każdego na świecie, kto ma dostęp do Internetu" ${ }^{20}$. W analogiczny sposób Internet powinien stać się medium, dzięki któremu misję swoją prowadzić będą uniwersytety.

Współczesne wspólnoty uniwersyteckie świetnie radzą sobie w wykorzystywaniu nowych mediów w procesie kształcenia i szerzenia swoich ideałów oraz realizacji wyznaczonych sobie celów. Po okresie

\footnotetext{
18 Tadeusz Czeżowski pisał: „W wyższych szkołach zawodowych obciąża się studentów obowiązkowymi zajęciami, zwłaszcza rozlicznymi ćwiczeniami, podczas gdy w uniwersytecie należy dać studentowi większą swobodę, położyć nacisk na jego aktywną postawę, wymagać od niego samokształcenia i dawać mu wskazówki w tym kierunku". Tamże, s. 239.

${ }_{19}$ T. Wołoszyn, Etos społeçeństwa polskiego na progu XXI wieku a ewangelizacja, Bobolanum, Warszawa 1994, s. 130.

${ }^{20}$ M. Robak, Czy Kościót lubi Internet?, w: Internet i nowe technologie, dz. cyt., s. 63.
} 
nieufności i sceptycyzmu wobec nowych technologii oraz Internetu nastał okres, kiedy nie sposób wyobrazić sobie funkcjonowanie uniwersytetu czy jakiejkolwiek uczelni wyższej bez Internetu $\mathrm{i}$ w oderwaniu od nowych mediów. Coraz częściej studenci za pomoca Internetu i wyspecjalizowanych programów komputerowych moga zapisać się na wybrane zajęcia, poczta wirtualna stała się standardowym sposobem kontaktu studentów z wykładowcami, w sieci znaleźć można mnóstwo materiałów naukowych przydatnych w procesie kształcenia, w sieci również zamieszczane są publikacje studentów oraz uczonych, coraz więcej uniwersytetów tworzy sieci tzw. „bibliotek cyfrowych”, będących zbiorem publikacji dostępnych dla szerokiej rzeszy odbiorców ${ }^{21}$. Internet stał się szerokim forum wymiany myśli i poglądów, miejscem dyskusji, sporów i kłótni. Jakkolwiek każda dyskusja odbywająca się nie w formie ustnej, a za pośrednictwem różnego rodzaju mediów ,jest powolna, nieraz żmudna, wymaga dużo wysiłku pisarskiego", to jednak zapewnia każdemu z dyskutantów dość czasu do namysłu i przygotowania wypowiedzi ${ }^{22}$.

W sieci ponadto łatwiej znaleźć ludzi o upodobaniach i zainteresowaniach zbliżonych do naszych, łatwiej nawiązać kontakt z osobą zajmująca się naszą „działką badawczą", łatwiej uzyskać informacje dotyczące spotkań, zjazdów, zlotów, wydawnictw czy najważniejszych wydarzeń naukowych w dziedzinie nas zajmującej. Paul Levinson pisał o tym, jak w Internecie ludzie nawiązuja nowe znajomości, „pojawiaja się liderzy, zanikaja, ich miejsce zajmuja nowi, uczestnicy dzielą się informacjami, uczą się nawzajem, nawiązują się przyjaźnie, wybuchają kłótnie, czasem ludzie się zakochują, czasem rodzą się silne antypatie, niektórzy uprawiaja miłość - wszystko za pomoca słów" ${ }^{23}$. Okazuje się, że dla współczesnego społeczeństwa - w szczególnym zaś stopniu dla osoby związanej z uniwersytetem, czy to jako jego pracownika, czy też studenta - wymiana informacji staje się najważniejsza. Filozofowie przestrzegają, że w takim społeczeństwie wiedza często zajmuje miejsce nadrzędne w stosunku do podmiotu tej wiedzy ${ }^{24}$. Aby jednak ochronić przed tym niebezpieczeństwem postuluja

\footnotetext{
21 A. Juchnowicz, Kolorowe obrazki, potę̇ne narz̧dzie czy złłodziej czasu?, w: Internet $i$ nowe technologie, dz. cyt., s. 110.

22 T. Czeżowski, O dyskusji i dyskutowaniu, w: Odcayty filozoficzne, dz. cyt., s. 195.

${ }^{23}$ P. Levinson, Miekekie ostrze, MUZA, Warszawa 1999, s. 203.

24 J.-F. Lyotard, Kondycja ponowoczesna, Wydawnictwo Aletheia, Warszawa 1997, s. 29. W tym miejscu nie zajmuja nas dalsze prognozy i oceny dokonywane przez Lyotarda w dalszej części jego książki, które wskazują na groźbę dalszej alienacji wiedzy względem jej użytkowników.
} 
zastapienie „edukacji monologowej”, w której „inny” - człowiek znajdujący się niejako „po drugiej stronie sieci” - jest nieważny, „edukacja dialogiczna”. Ideałem „edukacji dialogicznej” - wybitnie demokratycznej - byłoby nakierowanie na ,innego” poprzez dążenie do poznania jego tradycji, historii i kultury, nawiązania z nim rozmowy, dzięki której obie strony będą się kształcić i rozwijać. Taki model „komunikacji dialogicznej” opierałby się na wzajemnej wymianie informacji, wiedzy $\mathrm{i}$ doświadczenia ${ }^{25}$, miałby on umacniać stosunki podmiotowo-podmiotowe między osobami kontaktującymi się ze sobą i współtworzącymi proces edukacji ${ }^{26}$. Przykładem swoistym takiej „edukacji dialogicznej” byłby projekt uniwersytetów wirtualnych, czyli form kształcenia uniwersyteckiego odbywającego się całkowicie on line. Wykłady oglądane są przez studentów na ekranie komputera, testy rozwiązuje się w sieci, poprzez e-mail przesyła się wersje elektroniczne prac pisemnych, również e-mail i fora internetowe służą do kontaktów między studentem a wykładowcą oraz między poszczególnymi studentami.

Model „edukacji dialogicznej” to model wybitnie demokratyczny. Dystans między wykładowca a studentem ograniczony zostaje tylko i wyłącznie do dystansu, jaki tworzy Internet. Ponadto w edukacji wirtualnej „zasada demokratyczna” zajmuje miejsce - typowej dla tradycyjnych uniwersytetów - „zasady arystokratycznej” przyjmującej, że „arystokracja w nauce to krąg mistrzów i luminarzy, którzy (bez względu na swe uchybienia i grzechy, które ich nie dyskwalifikują moralnie i intelektualnie) chcą i potrafią być nauczycielami i przodownikami gry o prawdę naukową uprawianej na sposób zgodny $z$ ethosem nauki”. W edukacji opierającej się na „zasadzie demokratycznej” wszyscy uczestnicy gry są równouprawnieni, maja prawo w takim samym stopniu dbać o trwanie i rozwój nauki ${ }^{27}$. W efekcie system taki sprawia, że człowiekowi zdolnemu w jego działalności naukowo-badawczej nie staja na przeszkodzie hierarchicznie zorganizowane instytucje, $w$ funkcjonowaniu których nie jest on zorientowany. Z drugiej jednak strony system ów sprawia, że często do głosu dochodzą miernoty i ludzie „niedokształceni”, czego przyczynami sa: ograniczona selekcja oraz

25 W. Prokopiuk, Humanistyczne ukierunkowanie nauczyciela akademickiego jako miara jego etyczności w kontekśsie globalizacji, w: Etos pedagogów i edukacji, dz. cyt., s. 69.

26 Tamże, s. 72.

${ }^{27}$ J. Goćkowski, Ethos nauki i role uczonych, Wydawnictwo i Drukarnia „Secesja”, Kraków 1996, s. 284-285. 
hołubienie pluralizmu poglądów czy wolności naukowej działalności ${ }^{28}$. W efekcie pytanie o naukowa prawdę odsunięte zostaje na plan dalszy, na planie pierwszym zaś pojawia się postmodernistyczne przekonanie o istnieniu mnogości prawd. Internet i edukacja wirtualna sprawiają więc, że uniwersytety $\mathrm{w}$ coraz większym stopniu narażone są na hasła relatywizmu czy wręcz nihilizmu (w mniejszym stopniu dotyczy to oczywiście nauk ścisłych i przyrodniczych, w większym - humanistyki i nauk społecznych). Istnieje więc ryzyko, że współczesne uniwersytety staną się wyłącznie swoistymi forami prezentacji poglądów, nie zaś miejscem gruntownego kształcenia oraz przygotowania do życia społecznego.

Jeśli zaś chodzi o życie we współczesnym społeczeństwie, to stawia ono przed człowiekiem szereg wyzwań, którym musi on sprostać. Kształcenie wirtualne zapewnia człowiekowi kształcącemu się mnóstwo instrumentów, by w dzisiejszym świecie się odnaleźć. Dzięki Internetowi stajemy się bardziej mobilni - nie tylko ze względu na łatwość nawiązywania kontaktów i zdobywania informacji w sieci - uczymy się bowiem mechanizmów funkcjonowania państw i społeczeństw liberalnodemokratycznych. Człowiek mobilny i kształcący się z uwzględnieniem szerokiego wachlarza technik innowacyjnych i multimedialnych, to człowiek ciekawy świata, zainteresowany sprawami społecznymi i politycznymi. Internet nie tylko pozwala nam poznać dalekie kraje, kultury i cywilizacje, zaplanować sobie daleką podróż, ale również nauczyć się języka obcego (na odpowiednim portalu internetowym czy używając zakupionego programu komputerowego) ${ }^{29}$. Problem jednak w tym, że największy kapitał na rozwijaniu „edukacji wirtualnej” zbijaja największe światowe firmy komputerowe i medialne, które doprowadziły do ekstremalnej w porównaniu z czasami wcześniejszymi komercjalizacji informacji i wiedzy, która „została w szczególny sposób sprywaty rowana i zawłaszczona przez wielkie centra kapitału zarówno prywatnego, jak i państwowego", stąd owo forum idei, o którym mówi tak wielu apologetów demokracji zglobalizowanej, w rzeczywistości stanowi rynek

${ }^{28} \mathrm{~J}$. Goćkowski wskazuje na następujące wolności uczonych: 1) swoboda poszukiwań i dociekań naukowych, 2) swoboda wymiany poglądów między ludźmi nauki, 3) swoboda ogłaszania prac naukowych, 4) swoboda wyboru koncepcji i stylu grania ról będących wykonywaniem zawodu pracownika naukowego, 5) swoboda urządzania współdziałania w postaci małych grup pracy naukowej, tzn. wolność tworzenia i kształtowania przez samych zainteresowanych kolegów cechowych wielorakich form i stylów działania zespołów badawczych i seminariów uniwersyteckich, 6) swoboda tworzenia towarzystw naukowych - kanon praw kardynalnych cechu uczonych. Zob. Tamże, s. 313-315.

${ }^{29}$ E. Kubiak-Szymborska, dz. cyt., s. 38-39. 
informacji $1^{30}$. Rynek ów jest tym bardziej istotny, w im większym stopniu poszerza się w naszym życiu owa sfera zinformatyzowana. Już dziś komputer jest naszym urzędem pocztowym, służy nam za telefon, odtwarzacz wideo, jest naszym miejscem pracy i miejscem odpoczynku, coraz częściej robimy tutaj zakupy i „spotykamy się” z przyjaciółmi.

\section{Największe niebezpieczeństwa nowoczesnej edukacji}

Upowszechnianie się nowych form edukowania budzi niepokój zwolenników edukacji tradycyjnej a także tych, którzy do tradycyjnych metod i technik kształcenia zdążyli się przywiązać. A. Juchnowicz pisze z sentymentem, że „superszybki komputer, potrafiący dotrzeć do trzydziestu pięciu milionów adresów i porównać niezliczoną ilość dokumentów, jest na pewno wspaniałym narzędziem pracy, ale tradycyjnego bibliotecznego katalogu nigdy nie zastapi. Ciagłość i dokładność, będące gwarancja przejrzystości każdego katalogu, oraz dostępność do przechowywanych w bibliotece dokumentów, to cechy, których na próżno szukać w Internecie. (...) Ogólnie dostępny, zawsze czynny magazyn, skład, depozyt, a nie biblioteka - oto czym jawi się Internet" 31 . Tutaj bardzo często Internet przyrównuje się do telewizji, w której również przed kilkudziesięciu laty widziano przekaźnik treści edukacyjnych i kanał krzewienia kultury wysokiej, stał się zaś i jest po dziś dzień uznawana przede wszystkim za „medium masowej kultury, trywialnej i niskiej rangi, promującej postawy konsumpcjonizmu i bierności. Telewizja jest na usługach przemysłu rozrywkowego, handlu, polityki" 32 . Medioznawcy i językoznawcy dodatkowo wspominają o tzw. ,„jezykowej mizerii” tak w odniesieniu do telewizji, jak i do Internetu: język przekazów medialnych staje się coraz bardziej ubogi i nieprzejrzysty, co w oczywisty sposób wpływa na ubóstwo myślenia oraz „otępienie" procesów kognitywnych ${ }^{33}$.

Problemem edukacji wirtualnej jest również zanik wartości wspólnoty lub - kiedy ta specyficzna wspólnota już powstanie - słabość jej oraz kruchość więzi między jej członkami ${ }^{34}$. Nowo tworzące się swoiste „e-wspólnoty” są bardziej anonimowe, przez co mamy w nich do czynienia z załamaniem niektórych przynajmniej mechanizmów kontroli

\footnotetext{
${ }^{30}$ M. Hetmański, dz. cyt., s. 33.

31 A. Juchnowicz, dz. cyt., s. 110.

32 M. Hetmański, dz. cyt., s. 36.

33 M. Ostrowska, Etos jezyka edukacji w kontekśsie problemów globalizacji, w: Etos pedagogów $i$ edukacii, dz. cyt., s. 187.

${ }^{34}$ T. Zasępa, Media publiczne a wiezi społeczne, w: Internet i nowe technologie, dz. cyt., s. 88.
} 
społecznej. To z kolei sprawia, że rodzi się potrzeba budowania nowej etyki, etyki szczegółowej, która zajmowałaby się procesami związanymi z używaniem nowych technologii teleinformatycznych. Etyka komputerowa czy też cybernetyka byłaby najważniejszym działem etyki w zgloblizowanym świecie. Opierać się powinna na takich współczesnych wartościach, jak: swobodny dostęp do sieci i informacji, poszanowanie prawa własności, troska o dokładność i wiarygodność informacji oraz respektowanie sfery prywatnej jednostki ${ }^{35}$. Najważniejszym więc zadaniem cybernetyki powinno być formułowanie wytycznych pozwalających na odpowiedzialne korzystanie z Internetu i innych mediów ${ }^{36}$. Medioznawcy katoliccy również dostrzegają konieczność budowania cybernetyki. Ks. T. Zasępa jest zwolennikiem aktywnego zaangażowania się Kościoła Katolickiego w życie wspólnot internetowych, bowiem każda wspólnota jest przez niego traktowana jako wartość. Obecność Kościoła w „e-wspólnotach” nazywa Zasępa „obecnościa porządkującą"37. Taka „obecność porządkująca” wydaje się bardzo potrzebna we współczesnym świecie zglobalizowanym, a także we współczesnym świecie nauki. Ludzie nauki coraz częściej, w pogoni za zawodowym sukcesem i szybką kariera, zapominają o wartości, jaka jest wspólnota uniwersytecka, zapominaja o prawdzie, której powinni służyć. Pluralizm współczesności niejednokrotnie powoduje odsuwanie na plan dalszy kwestii aksjologicznych i etycznych, zaś ,,wołanie o świat wartości jest niejednokrotnie wołaniem osamotnionego w bezbrzeżnym tłumie głuchych" 38. Cybernetyka ma służyć również młodym naukowcom poruszającym się w świecie wirtualnym, otwierać ich na refleksję aksjologiczną i skłaniać do moralnych ocen w stosunku do własnych odkryć, badań i analiz.

Świat zglobalizowany to świat opierający się na swobodzie przepływu informacji, ale również na swobodzie przepływu kapitału. Z oczywistych względów ma to swoje odzwierciedlenie również w środowiskach naukowych. Nauka w przeciagu ostatnich kilkudziesięciu lat dzięki swobodnemu przepływowi kapitału mogła rozwijać się jak nigdy przedtem. Młodym naukowcom łatwiej pozyskiwać pieniądze na badania, łatwiej publikować. Z drugiej jednak strony coraz częściej tradycyjna uniwersytecka relacja między mistrzem a uczniem zastapiona

\footnotetext{
35 A. Lekka-Kowalik, dz. cyt., s. 17-23.

${ }^{36}$ M. Robak, dz. cyt., s. 65.

${ }^{37}$ T. Zasępa, Komunikacja cybernetyczna wyzwaniem dla Kościoła, w: Internet $i$ nowe technologie, dz. cyt., s. 52-53.

38 W. Sawczuk, dz. cyt., ss. 43 i 49.
} 
zostaje relacją między patronem a klientem ${ }^{39}$. Dążenie do prawdy niejednokrotnie zastępowane jest zabieganiem o sukces materialny czy finansowy, kategoria dobra ulega przedefiniowaniu. Tadeusz Czeżowski kazałby zapewne zastanowić się nad kulturą moralną współczesnego środowiska uniwersyteckiego, a kulturę moralna - według niego posiada „ten, kto wie, co dobre, a co złe, i potrafi pod tym względem ocenić postępowanie swoje i cudze, a zarazem w postępowaniu dążyć do dobra, a zła unikać" ${ }^{40}$. Kultura moralna właśnie w świecie naukowym wydaje się wyjątkowo ważna: pracownik naukowy bowiem $z$ jednej strony ma być poszukiwaczem prawdy, racjonalnym, rzetelnym i obiektywnym obserwatorem rzeczywistości, z drugiej zaś - opiekunem, wychowawca, nauczycielem i mistrzem. Nowe drogi edukacji, w szczególności jednak Internet, kontynuować powinny te elementy tradycyjnego ethosu uniwersyteckiego, które wydają się ponadczasowe i uniwersalne. Nie może to być jednak tożsame z odrzucaniem innowacyjności i zamknięciem na zmiany tegoż ethosu.

\section{Ethos uniwersytetu - synteza tradycji z nowoczesnością}

Wielu współczesnych etyków, pedagogów i medioznawców podczas dyskusji nad stanem współczesnej edukacji i kondycji naukowców oraz nauczycieli wskazuje na konieczność aksjologicznego ukierunkowania procesu edukacji. Młody człowiek - uczeń oraz student - ma być „uczony aksjologii”, ale również „wychowywany do wartości”, nauczyciele oraz wykładowcy mają mu pomóc w osiąnięciu „dojrzałości aksjologicznej" ", dzięki której możliwe będzie odróżnienie dobra od zła i prawdy od fałszu. Tadeusz Czeżowski w swoich pismach zawsze obok walorów intelektualnych - wspominał o walorach moralnych późniejszych pracowników uniwersytetu oraz naukowców, potrzebnych do tego, aby - obok funkcji badawczo-poznawczej - móc godnie realizować również funkcję nauczycielsko-wychowawczą ${ }^{42}$. Wydaje się, że edukacja wirtualna, choć rzeczywiście w większym stopniu niż tradycyjna, narażona jest na pomijanie czynnika moralnego, to jednak próbować może również ten wymóg urzeczywistniać. Otwartość na innych ludzi, inne kultury czy inne poglądy, jaką zapewnia Internet oraz współczesne media masowe, nie muszą prowadzić do relatywizmu czy

39 J. Goćkowski, dz. cyt., s. 291.

40 T. Czeżowski, O ideale uniwersytetu, w: Pisma z etykei i teorii wartości, dz. cyt., s. 241.

${ }^{41} \mathrm{~K}$. Olbrycht, Etos pedagoga a jego rola w ksztatceniu aksjologicznym na progu XXI wieku, w: Etos pedagogów $i$ edukacji, dz. cyt., s. 101-102.

${ }^{42}$ T. Czeżowski, O ideale uniwersytetu, w: Pisma z. etykei i teorii wartości, dz. cyt., s. 239. 
indyferentyzmu, ale uczyć szacunku dla drugiego człowieka a także dystansu i krytycyzmu względem samego siebie i własnych poglądów. Również niekonkluzywność dyskusji w świecie wirtualnym może być jedynie pozorna, gdyż - jak pisał sam Czeżowski - „także taka pozornie bezowocna dyskusja jest pożyteczna, pozwala bowiem uczestnikom na dokładne poznanie różnic, które ich dzielą i na zrozumienie wzajemne swoich stanowisk" ${ }^{\prime 43}$.

Jeśli zaś chodzi o walory intelektualne, to wydaje się, że także w ramach kształcenia wirtualnego czy multimedialnego moga one być realizowane i promowane. Tutaj Czeżowski wymienia: systematyczność w pracy jako przeciwieństwo dorywczości (era Internetu sprawia, że pracować można zawsze i wszędzie, bezprzewodowy dostęp do sieci możliwy jest z niemalże każdego miejsca na świecie), dokładność jako przeciwieństwo powierzchowności (możliwość wyszukiwania w sieci wszelkiej maści informacji, sprawdzania ich i konfrontowania), sumienność jako przeciwieństwo lekkomyślności, rzetelność jako przeciwieństwo obłudy, samodzielność myśli i odwaga przekonań, nie ulegająca autorytetom (Goćkowski zwie to ,nieposłuszeństwem w myśleniu"; niewatpliwie nowe media są swoistą areną realizacji takiej wolności) oraz krytycyzm wobec siebie samego i życzliwa tolerancja dla poglądów cudzych (możliwe dzięki nieograniczonym kontaktom z ludźmi różnych kultur i światopoglądów) ${ }^{44}$. Okazuje się, że można być naukowcem pracującym on line i realizującym jednocześnie ideał uniwersytetu wskazany przez Czeżowskiego. Edukacja wirtualna i uniwersytety multimedialne nie muszą oznaczać końca tradycyjnego ethosu uniwersytetu i - choć z oczywistych względów świat doby konsumpcjonizmu i globalizacji narażaja ów ethos na szereg zagrożeń i niebezpieczeństw - mogą wzbogacać go przystosowując jednocześnie do zmieniającego się świata. Konieczne jest jednak zdecydowane nastawienie tej nowej edukacji na troskę o dojrzałość aksjologiczną i wychowanie moralne młodego człowieka, aby jego działalność naukowobadawcza i dążenie do prawdy - niezależnie od dziedziny, której ów człowiek się poświęci - nigdy nie kolidowały z szacunkiem dla drugiego człowieka.

\footnotetext{
${ }^{43}$ Tenże, O dyskusji i dyskutowaniu, w: Odcayty filozoficzne, dz. cyt., s. 194.

44 Tenże, Dydaktyka filozofii w nauczaniu uniwersyteckim, w: Odczyty filozoficzne, dz. cyt., s. 214-215.
} 